\title{
As raízes do Brasil em Leite derramado, de Chico Buarque
}

\author{
Lílian Paula Serra e Deus ${ }^{1}$
}

Chico Buarque é conhecido e consagrado por suas obras musicais, teatrais e também pelos vários romances publicados até agora. Segundo Meneses, "compositor, dramaturgo e ficcionista se encontram, derrubando barreiras de gêneros e de formas, sob o signo do poeta" (Meneses, 2002, p. 17). Peças teatrais como Roda viva (1968), Calabar: o elogio à traição (1974), Gota d'água (1975), Ópera do malandro (1978), são marcos importantes na carreira de Chico Buarque enquanto dramaturgo e são bastante significativas para o cenário teatral brasileiro. Algumas de suas peças, como Ópera do Malandro e Calabar, encenam e promovem novas possibilidades de olhar para o passado histórico brasileiro.

Chico Buarque escreve seu primeiro texto literário entre 1961 e 1964, o livro de poesias intitulado A bordo do Rui Barbosa, o qual só publica em 1981. Em 1974, Buarque publica a novela Fazenda modelo e, cinco anos mais tarde, em 1979, tem o livro infantil Chapeuzinho amarelo publicado. Posteriormente, em 1990, o autor lança o romance Estorvo e, em 1995, publica o romance Benjamin. Em 2003, Buarque traz a público o romance Budapeste e, em 2009, Leite derramado, cuja inspiração o autor diz ter surgido ao ouvir uma canção, de sua autoria, na voz de Mônica Salmaso, da qual ele nem se lembrava mais.

A canção $O$ velho Chico, escrita em 1987, traz em sua letra a história de um ex-escravo, centenário, abandonado em um asilo, local no qual rememora suas histórias, comprometidas por seu estado senil. É interessante observar que o lapso de memória do autor foi o ponto de partida para a construção dos lapsos de memória do narrador Eulálio. Sobre o título do romance Leite derramado, talvez munido da mesma ironia que acompanha a sua personagem Eulálio, o autor relata, em entrevista ao jornal Público, de Portugal, o seguinte:

Durante a escrita isso começou a atormentar-me um pouquinho. Apareceu a cena do leite derramado na pia, eu acho curioso isso de usar uma expressão batida - leite derramado, chorar sobre

${ }^{1}$ Doutora em letras e professora no Instituto Federal do Norte de Minas Gerais (IFNMG), Almenara, MG, Brasil. E-mail: lilianedeus@gmail.com 
leite derramado -, mas o leite derramado, literalmente, está ali na pia. Quando escrevi aquela cena - eu falo cena como se fosse um filme - achei interessante utilizar esse título. Eu gostava e não gostava. É um título que parece um clichê, um pouco vulgar. Até hoje penso um pouquinho: "Parece título de livro ruim"! [risos]. Depois pensei: "Mas Chico também é um nome de escritor ruim" [mais risos] (Buarque, 2009b).

\section{Leite derramado: identidades, raízes}

Leite derramado abarca em seu enredo a história de prosperidade e decadência de uma família. Na narrativa de Buarque, a história familiar de Eulálio entrelaça-se à história do Brasil. É possível perceber que a família desse senhor centenário ocupou lugar de destaque no cenário político brasileiro ao longo de séculos. Mas, para além de delimitar os cargos públicos e os espaços de poder ocupados pelos ascendentes de Eulálio, faz-se necessário perceber as estratégias de construção textual das quais o autor se vale para criar uma personagem que, ao falar da família, algo que denota ao particular, entoa também um discurso que abarca o âmbito público. Fundem-se, pelo viés do relato memorialístico de Eulálio, duas sociedades: uma microssociedade particular e privada, que circunscreve as relações particulares do sujeito, e outra macrossociedade pública. Essa imbricação de espaços públicos e privados na qual Eulálio se inscreve transcende ao indivíduo e conota aos alicerces da sociedade brasileira, cujas relações confusas e imbricadas, entre espaços públicos e privados, sempre se fizeram presentes.

Quem é Eulálio? Quais as características que permeiam essa personagem? Qual a identidade desse senhor centenário? Que valores ela abarca?

Ao perscrutar a respeito da identidade de Eulálio, a própria identidade brasileira é posta em questão, partindo-se da premissa de que Eulálio é o representante de heranças comportamentais brasileiras seculares. Diante dessa perspectiva, Eulálio pode ser lido enquanto sujeito do entrelugar: estando entre o público e o privado, ele é a metáfora daquele a quem Sérgio Buarque de Holanda denomina "homem cordial", do qual a história política brasileira tem se valido desde sempre.

Sérgio Buarque de Holanda, em Raízes do Brasil (2014), ao discorrer sobre a história do Brasil e seus alicerces, discorre também acerca da identidade herdada e afirmada pelo brasileiro ao longo de séculos. 
Segundo o autor, somos um povo cujas raízes estão vincadas ao patriarcalismo e ao personalismo, herdados dos povos ibéricos. $\mathrm{O}$ autor de Raízes do Brasil (2014), ao falar dos domínios rurais que marcaram o período colonial brasileiro e das heranças que eles abarcam, sublinha que repercutimos padrões políticos correlacionados a padrões familiares: vida pública e privada se misturam, de tal maneira, que o brasileiro é envolto, desde os tempos coloniais, por um espírito de facção que circunscreve as relações familiares e, portanto, privadas, mas também as relações públicas, sendo a política um exemplo desse espírito apregoado e disseminado por nosso patriarcado rural:

A opinião de que um indivíduo filiado a determinado partido político assumiu, pelo fato dessa filiação, compromissos que não pode romper sem felonia pertence de modo bem distinto a um círculo de ideias e princípios que a ascensão da burguesia urbana tenderia a depreciar cada vez mais. Segundo tal concepção, as facções são constituídas à semelhança das famílias, precisamente das famílias de estilo patriarcal, onde os vínculos biológicos e afetivos que unem ao chefe os descendentes, colaterais e afins, além da famulagem e dos agregados de toda sorte, hão de preponderar sobre as demais considerações. Formam, assim, como um todo indivisível, cujos membros se acham associados, uns aos outros, por sentimentos e deveres, nunca por interesses ou ideias (Holanda, 2014, p. 93).

Sérgio Buarque de Holanda (2014) afirma, portanto, que toda a estrutura de nossa sociedade colonial teve sua base nos meios rurais. Além de relacionar a formação da sociedade brasileira a valores herdados dos povos ibéricos, enfatiza que, nos domínios rurais, há um tipo de formação familiar que prevalece como base e centro de toda a organização e dela fazem parte "os escravos das plantações e das casas, e não somente escravos, como agregados, [que] dilatam o círculo familiar e, com ele, a autoridade imensa do pater-famílias" (Holanda, 2014, p. 95). Ainda segundo o autor, essa organização familiar segue os modelos apregoados pelo direito romano-canônico, mantidos na península Ibérica, através de inúmeras gerações. Sérgio Buarque de Holanda evidencia que:

Esse núcleo bem característico em tudo se comporta como seu modelo da Antiguidade, em que a própria palavra "família", derivada de famulus, se acha estreitamente vinculada à ideia de escravidão, e em que mesmo os filhos são apenas os membros 
livres do vasto corpo, inteiramente subordinado ao patriarca, os liberi (Holanda, 2014, p. 96).

O autor aponta também para o fato de que, entre vários setores de nossa sociedade colonial, a esfera da vida doméstica resistiu ao tempo. Segundo ele, "o quadro familiar torna-se, assim, tão poderoso e exigente, que sua sombra persegue os indivíduos mesmo fora do recinto doméstico. A entidade privada precede sempre, neles, a entidade pública" (Holanda, 2014, p. 96). Portanto, a organização privada, em que, segundo Sérgio Buarque de Holanda, prevalecem necessariamente as preferências fundadas em laços afetivos, marca a nossa sociedade, nossa vida pública e todas as nossas atividades. Em nossa vida social imbricam-se "sentimentos próprios à comunidade doméstica, naturalmente particularista e antipolítica, uma invasão do público pelo privado, do Estado pela família" (Holanda, 2014, p. 97).

De maneira equivocada, nossas práticas políticas fundiram o público e o privado de tal forma que o Estado passou a ser percebido como uma espécie de ampliação da organização familiar. Sérgio Buarque de Holanda acentua esse equívoco ao sublinhar que:

O Estado não é uma ampliação do círculo familiar e, ainda menos, uma integração de certos agrupamentos, de certas vontades particularistas, de que a família é o melhor exemplo. Não existe, entre o círculo familiar e o Estado, uma gradação, mas antes uma descontinuidade e até uma oposição. A indistinção fundamental entre as duas formas é prejuízo romântico que teve os seus adeptos mais entusiastas durante o século XIX. De acordo com esses doutrinadores, o Estado e as suas instituições desceriam em linha reta, e por simples evolução, da família (Holanda, 2014, p. 169).

Sérgio Buarque de Holanda deixa claro em seu discurso que família e Estado, apesar de não terem sido tratados dessa maneira na sociedade brasileira, pertencem a ordens diferentes em essência. Segundo o estudioso, somente através da transgressão da ordem doméstica e familiar é que nasce o Estado.

Nesse sentido, muitas correlações podem ser estabelecidas entre o discurso de Sérgio Buarque de Holanda (2014) e o romance Leite derramado, de Chico Buarque. Eulálio, pelos caminhos da ficção, é o legado do patriarcado rural que se instaura na sociedade brasileira desde os primórdios. Ele é o descendente desse Brasil rural e escravocrata que se formou exaltando a figura dos patriarcas. A 
personagem tem seus ascendentes, desde o tetravô até o pai, relatados como figuras importantes de poder pertencentes ao período colonial, imperial e republicano do Brasil.

Ressalta-se que o narrador de Leite derramado, ao mesmo tempo que se aproxima dessa herança familiar, a repudia:

Eu não queria ser Eulálio, só mesmo os padres me chamavam assim nos tempos de colégio. A me chamar Eulálio, preferia envelhecer e ser sepultado com meus apelidos infantis, Lalinho, Lalá, Lilico. O Eulálio do meu tetravô português, passando por trisavô, bisavô, avô e pai, para mim era menos um nome do que um eco (Holanda, 2009a, p. 31).

Eulálio tem aversão a sua identidade, ao nome com o qual foi registrado, e prefere ser chamado por apelidos, mas, por outro lado, tem comportamentos que o aproximam de seus familiares, como os preconceitos que o fazem condenar as variantes linguísticas que fogem à "norma culta" ou à variante padrão. Ao renegar o próprio nome, a personagem repudia essa identidade que ressoa outras pretéritas, já que ele possui o mesmo nome do tetravô, bisavô, avô e pai. É como se o nome da personagem, reiterado há várias gerações, trouxesse também uma identidade que acompanha o Brasil e que se perpetua ao longo dos séculos.

Merece ser ressaltado que Balbino, "o ex-escravo alforriado", também possui o mesmo nome de seus ascendentes. Através da estratégia de construção de personagens masculinos com o mesmo nome, o autor reconstrói, no plano da ficção e de maneira bastante irônica, histórias e personagens que se repetem ao longo da história do país. O nome Eulálio, como já destacado, retoma o período imperial, no qual seu tetravô foi "um figurão do império", mas também o regime escravocrata e o período republicano, abarcado, principalmente, por seu pai, que era senador.

A personagem Balbino, trazida através das memórias de Eulálio, retoma as memórias da escravatura no Brasil. E quando colocados lado a lado, Eulálio e Balbino repisam as relações estabelecidas entre senhor e escravo nos tempos coloniais e o preconceito racial que ainda persiste no Brasil. Na citação que se segue, a metáfora "entrar na família sem sapatos", alude à condição de Balbino na família: a relação de exploração fica conotada, já que os sapatos são o símbolo da alforria dos escravos:

Assunção, na forma assim mais popular, foi o sobrenome que aquele escravo Balbino adotou, como a pedir licença para entrar na família sem sapatos. Curioso é que seu filho, também Balbino, foi cavalariço 
do meu pai. E o filho deste, Balbino Assunção Neto, um preto meio roliço, foi meu amigo de infância (Holanda, 2009a, p. 18).

Cabe ressaltar no momento que, para além do viés histórico ou estilístico, a narrativa buarquiana embaralhara tradições: ao mesmo tempo que as tradições culturais brasileiras são postas em questão, a tradição literária também é conclamada. Os modos de narrar assumidos pela narrativa buarquiana possibilitam ao leitor estabelecer correlações entre Eulálio e Matilde e muitas outras personagens da nossa tradição literária. Muitos críticos têm relacionado o romance Leite derramado à narrativa machadiana. Alguns questionamentos surgem dessa correlação: quais aproximações podem ser estabelecidas entre Matilde e Capitu, por exemplo? E que intertextos podem ser estabelecidos entre a personagem buarquiana Eulálio e as personagens machadianas contidas em Memórias póstumas de Brás Cubas e Dom Casmurro? O olhar de pingue-pongue de Matilde dialogaria com o olhar de ressaca de Capitu?

Para além das comparações que perpassam a tradição literária brasileira, Leite derramado também é comparado a obras clássicas de tradições literárias universais, como aponta, por exemplo, Alexsandra Sarmento (2015), ao relacionar Matilde, personagem buarquiana, à Matelda, personagem da Divina Comédia, de Dante. Ao que parece, do mesmo modo que Leite derramado pode ser lido na esteira da tradição da elite brasileira, cujos traços retomam considerações feitas em Raízes do Brasil, a personagem Matilde pode ser vista em diálogo com personagens que retomam tradições literárias, sejam elas brasileiras ou universais. A personagem alude também a muitas das figuras femininas abarcadas pelas canções de Chico Buarque, mas, para além disso, Matilde e Eulálio são o ressoar de toda uma tradição literária que, ao dialogar com a narrativa buarquiana, é ressignificada e atualizada. Portanto, Matilde é e não é Capitu; é e não é Iracema; é e não é Matelda. O mesmo pode-se dizer de Eulálio: a personagem tem características que a aproximam e a afastam de Brás Cubas, Bentinho, Édipo etc. A narrativa, quando estrategicamente estabelecida a partir do olhar do narrador, propicia aproximações com o discurso do narrador Bentinho, do romance machadiano, suscitando no leitor alguns questionamentos: Que narrador é esse? Como ele é caracterizado? Seu discurso é imparcial ou é atravessado por sentimentos como o ciúme?

No que tange às aproximações entre Eulálio e Édipo, pode-se conjecturar que há no narrador do romance buarquiano uma questão 
edipiana mal resolvida e, consequentemente, uma fixação pela figura materna. Faz-se oportuno ressaltar a importância que a imagem do pai de Eulálio assume na narrativa: o narrador Eulálio Montenegro d'Assumpção, estrategicamente, possui o mesmo nome de seu pai e parece perseguir a imagem desse pai, ora confrontando-a, enxergando na figura paterna um rival, ora desejando neuroticamente ocupar seu lugar, como denotado pelos trechos a seguir. No primeiro excerto, Eulálio nega o "nome do pai"; no segundo, fica denotada a sugestão de ocupar o lugar do pai ao lado da mãe. Eulálio, através da estratégia do deslizamento, transpõe para Matilde o desejo que sentia pela mãe, na infância:

Matilde falou Eulálio, e me confundiu. Tive um arrepio pelo sopro quente em meu ouvido, e outro arrepio a contrapelo, por ouvir um nome que quase me humilhava. Eu não queria ser Eulálio, só mesmo os padres me chamavam assim nos tempos de colégio. A me chamar Eulálio, preferia envelhecer e ser sepultado com meus apelidos infantis, Lalinho, Lalá, Lílico (Holanda, 2009a, p. 30).

E aí revivi uma sensação de menino, nas primeiras vezes que atentei para mulheres [...] demorei a acreditar que o meu desejo pudesse se restaurar a essa altura da vida, tão forte quanto nos dias em que Matilde me olhava como seu fosse o maior homem do mundo. Mas sim eu era de novo o rei do mundo, eu era quase o meu pai (Holanda, 2009a, p.180-181).

Ao negar o nome do pai, há implícita a negação da lei que a figura paterna representa e, por conseguinte, a questão freudiana do desejo do neurótico fica aparente.

Através da estratégia de construção textual de Leite derramado, o autor possibilita que muitas perspectivas sejam postas em diálogo: tradições históricas e literárias são colocadas lado a lado. Nesse sentido, o romance recupera o olhar do historiador Sérgio Buarque de Holanda, que se entrecruza com o olhar do filho, Chico Buarque, que, por sua vez, dialoga com tradições históricas, literárias e musicais várias.

Não por acaso, Chico Buarque constrói um narrador cujas memórias o leitor não pode afirmar se são póstumas ou não, a se considerar, sobretudo, a cena final da narrativa. Ao mesmo tempo que alude à narrativa de Memórias póstumas de Brás Cubas, por meio da construção textual, a dúvida a respeito das memórias de Eulálio, se póstumas ou não, marca a diferença entre as duas narrativas: o diálogo entre elas se faz presente, mas a diferença é evidenciada 
através da ressignificação: Brás Cubas é explicitamente um narrador póstumo, Eulálio traz a dúvida com relação a sua condição enquanto narrador. O ápice da dúvida surge ao final do romance, mais precisamente na última página, também mediado por uma estratégia que assume a memória a partir de repetições e retomadas de assuntos. Para a surpresa do leitor, o narrador discorre sobre uma morte, possivelmente a sua, alusão que já havia sido feita anteriormente. No primeiro momento aludido, o narrador descreve-se puxando o lençol e cobrindo o rosto, como trazido pelo excerto a seguir:

Por isso puxo o lençol e cubro meu outrora belo rosto, que logo tornam a expor para não parecer que estou morto, porque causa má impressão, ou é vexatório para maqueiro transportar defunto (Holanda, 2009a, p. 23).

$\mathrm{Na}$ página final da narrativa a cena anteriormente relatada é retomada da seguinte maneira:

Então abriu passagem uma jovem enfermeira, que se debruçou sobre meu tetravô, tomou suas mãos, soprou alguma coisa em seu ouvido e com isso o apaziguou. Depois passou de leve os dedos sobre suas pálpebras e cobriu com o lençol seu outrora belo rosto (Holanda, 2009a, p. 195).

A narrativa acaba, pois, como se espera do gênero romance, sem respostas definitivas e com o escopo de uma grande dúvida: seriam póstumas as memórias do narrador?

\section{Memórias}

Eulálio, personagem de Chico Buarque, é um senhor de idade tomado pela senilidade. Ele, por vezes, mostra-se lúcido e, em outros momentos, parece confuso, tomado pela fragilidade de suas lembranças. É interessante observar que os momentos de confusão de Eulálio geram certa dúvida no leitor.

$\mathrm{O}$ narrador se vale de suas memórias para relatar sua história, e o interlocutor parece mudar ao longo da narrativa. Por vezes, parece ser a enfermeira, em outros momentos, a filha que o visita no hospital ou o médico que o atende. A mudança de interlocutores pode ser percebida pelo excerto que se segue, em que Eulálio, em um primeiro momento, dirige seu discurso a um interlocutor somente identificado como "você", que não se sabe ao certo quem é. No mesmo trecho, o interlocutor 
identificado por "você" confunde-se com a enfermeira: "Acho que nem é da enfermagem", acabando por identificá-lo como a sua filha:

Não sei por que você não me alivia a dor. Todo dia a senhora levanta a persiana com bruteza e joga sol no meu rosto. Não sei que graça pode achar dos meus esgares, é uma pontada cada vez que respiro. Às vezes aspiro fundo e encho os pulmões de um ar insuportável, para ter alguns segundos de conforto, expirando dor. Mas bem antes da doença e da velhice, talvez minha vida já fosse um pouco assim, uma dorzinha chata a me espetar o tempo todo, e de repente uma lambada atroz [...] mas nem assim você me dá os remédios, você é meio desumana. Acho que nem é da enfermagem, nunca vi essa sua cara por aqui. Claro, você é minha filha que estava na contraluz, me dê um beijo (Holanda, 2009a, p. 10).

Por outro lado, o leitor, em passagem anterior, já percebeu que o discurso de Eulálio parece estar sendo dirigido a um de seus interlocutores, a enfermeira que transcreve a sua fala:

E falo devagar, como quem escreve, para que você me transcreva sem precisar ser taquígrafa, você está aí? (Holanda, 2009a, p. 7).

Por meio dessa estratégia textual, à medida que os relatos vão sendo escritos, possivelmente pela enfermeira, o romance vai também se tecendo, já que ele é construído a partir das lembranças relatadas por Eulálio. Essa estratégia irá formatar o livro ditado por Eulálio à enfermeira, que se tece no âmbito do enredo do romance que o leitor lê. Os dois livros, o ditado por Eulálio e o de Buarque, constroem-se por meio do "leite derramado" pelo narrador, ou seja, a partir do discurso memorialístico da personagem. Nesse sentido, o romance, ao retomar as memórias desse senhor, discorre acerca de si mesmo, sobre suas estratégias de construção, o que sinaliza para a ideia de uma metanarrativa: o romance encenando o próprio processo de escrita. Não é sem propósito que Eulálio dita suas memórias à pessoa que o ouve. Ao ditá-las com a finalidade de registrá-las, um livro vai sendo concebido também no que tange ao enredo, como já mencionado, e nele, Eulálio assume o papel de autor de suas próprias lembranças.

Faz-se necessário enfatizar que a estratégia de construção de um narrador, sabidamente porta-voz dos discursos da elite, cujas lembranças se fazem comprometidas, permite conjecturar que toda uma representação de memórias da elite a respeito do Brasil também é posta em xeque, juntamente com as memórias confusas do narrador. $\mathrm{O}$ 
discurso duvidoso de Eulálio descontrói, de certa maneira, as verdades impostas pela elite brasileira a respeito do Brasil e possibilita entrever outras verdades, já que a dúvida vai ao encontro de novas possibilidades de olhar. A narrativa, ao mesmo tempo que dá voz a um representante da elite, encena o esfacelamento dessa estrutura de poder brasileiro, que vai, ao longo do tempo, assim como Eulálio, adoecendo.

São muitos os índices que evidenciam que Eulálio ocupa espaços divergentes e conflituosos que a todo tempo têm de ser negociados. Enquanto se entrega ao passado, seja em razão da doença, seja por meio de suas memórias ou da não aceitação da destruição dos espaços do passado que cedem lugar à modernidade, ele planeja um casamento futuro, cuja suposta noiva parece ser a enfermeira que dele cuida:

Quando eu sair daqui, vamos nos casar na fazenda da minha feliz infância, lá na raiz da serra. Você vai usar o vestido e o véu da minha mãe, e não falo assim por estar sentimental, não é por causa da morfina. Você vai dispor dos rendados, dos cristais, da baixela, das joias e do nome da minha família (Holanda, 2009a, p. 5).

Quando eu sair daqui, vamos começar uma vida nova numa cidade antiga, onde todos nos cumprimentam e ninguém nos conheça (Holanda, 2009a, p. 29).

O narrador se apoia na senilidade e tem como alicerce suas lembranças, pois no presente se encontra deslocado de um real sentimento de pertencimento a um determinado lugar. Junto à perda dos espaços físicos, perde-se também um pouco da identidade de Eulálio, que só pode resgatada por meio de suas lembranças, já que no presente esses espaços não existem mais.

Os espaços que ele ocupava deram lugar a outros com os quais ele não mais se identifica. Portanto, ele não reconhece o espaço do presente como sendo seu verdadeiro lar. Há uma necessidade de busca do passado e um sentimento também de refugo é trazido à cena: o presente em que se vive hoje nega a velhice de tal forma que obriga os que estão nessa condição a fugir para tempos mais remotos. Nesse sentido, o apagamento dos locais que sinalizavam o espaço que a personagem ocupava no passado metaforiza a decadência do poder de uma elite que se esfacela com o tempo. Ainda assim, Eulálio insiste em reputar os locais do passado. Dessa maneira, ao reivindicar seu lugar no presente, Eulálio reitera a posição de da elite, que, mesmo adoentada, ainda se 
quer no poder. Dessa maneira, é válido observar a construção da personagem buarquiana: um idoso, com saúde e memória precárias. Em sendo a história familiar de Eulálio atravessada pela história do Brasil, a construção de uma personagem bastante velha e doente não poderia ser vista como a metáfora de um sistema político, também desgastado e bastante adoentado, em que o privado rasuraria o público? Eulálio, ao questionar a perda do lugar das tradições em contraposição à modernidade, vê-se também deslocado em relação ao lugar que ocupa e parece ser, em determinados momentos, a metáfora das tradições da elite brasileira: "A senhora já deve ter lido que em 1930 os gaúchos invadiram a capital, amarraram seus cavalos no obelisco e jogaram nossas tradições no lixo" (Holanda, 2009ª , p. 77).

Ao que parece, à medida que suas tradições vão se esvaindo, ele também se desconfigura, pois está muito atrelado a uma tradição familiar que remonta a sociedade brasileira desde os tempos do império até o século atual. Engendradas às críticas de Eulálio, há uma espécie de apego a um passado que se perde em nome da modernidade: "Quando eu morrer, meu chalé cairá comigo, para dar lugar a mais um edifício de apartamentos. Terá sido a última casa de Copacabana, que então se igualará à ilha de Manhattan, apinhada de arranha-céus"' (Holanda, 2009a, p. 49).

A questão linguística também coloca o narrador nesse espaço de negociação: Eulálio, como já dito, faz questão de fazer uso da variante padrão da língua e, por meio de seu discurso, fica evidenciado seu preconceito linguístico, já que se irrita com as falas de personagens que fogem à norma padrão e por vezes até as corrige. Para além disso, há resgatada, na fala do narrador, a fala de uma elite social preconceituosa. Ainda assim, Eulálio se casa com Matilde, que foge às normas da língua portuguesa e cujo comportamento ressoa uma atitude mais popular, contrária à das elites. A contradição é demarcada até mesmo pela maneira com a qual ela se veste, pelas músicas que ela ouve e pela cor de sua pele, que desperta o preconceito da mãe de Eulálio.

Ao recolher os fragmentos de sua memória, Eulálio retoma também a memória histórica do Brasil. A personagem, um senhor centenário que vivenciou várias passagens históricas importantes do país, faz parte de uma família que participou intensamente da política brasileira. Ao apresentar um sujeito em cuja história de vida ecoa a história política do país, para além do jogo metonímico instituído, a narrativa buarquiana assume um tom irônico bastante elucidativo. $\mathrm{Na}$ 
construção dessa personagem, há implícito um questionamento acerca de relações familiares e políticas que se estabeleceram desde o início na política brasileira. Eulálio é, pois, um representante da elite e, ao trazer ao presente o seu passado familiar, nele ressoam traços da "grande família" que marcou o cenário político brasileiro. Essa feição fica evidente no excerto a seguir: "Meu avô foi um figurão do império, grão-maçom e abolicionista radical, queria mandar todos os pretos brasileiros de volta para a África, mas não deu certo. Seus próprios escravos, depois de alforriados, escolheram permanecer na propriedade dele" (Holanda, 2009a, p. 15).

É importante, portanto, atentar-se para a função que a memória estabelece no romance e como se configuram as estratégias de lembrar/esquecer na narrativa.

Em Leite derramado, é através do cotidiano da personagem Eulálio que as memórias do Brasil vão sendo resgatadas. As lembranças do narrador retomam fragmentos do contexto histórico do país, desde o Império até o século XXI. O romance, como já enfatizado, é tecido a partir das memórias de um senhor que acabou de completar 100 anos de idade e que se encontra doente em uma cama de hospital. Ao se trazer para a cena um sujeito cujas memórias estão comprometidas, coloca-se em xeque também a memória oficializada pela história.

O nome da personagem é bastante significativo, pois Eulálio significa aquele que possui fluência ao falar ou uma "boa fala", e é exatamente na fala de Eulálio que o romance se ancora. À medida que as memórias do narrador vão sendo relatadas, o leitor vai percebendo uma espécie de memória histórico-linguística que tangencia sua fala. A estrutura da narrativa se tece por meio de uma linguagem que retoma o modo de falar de uma determinada classe social, mais precisamente da elite, em uma dada época da história do Brasil. A partir de um discurso que parece contínuo, elabora-se uma espécie de fluxo de consciência de um eu que se dirige a interlocutores que vão se alternando (médico, enfermeira, filha) e têm apenas o papel de ouvir e, no máximo, registrar as memórias de Eulálio.

É interessante observar que cada capítulo se constitui de um parágrafo único e contínuo, embora não linear, como que representando uma fala que se quer perene, quase sem interrupções. Em entrevista, de 2011, Chico Buarque esclarece a estrutura do romance: 
Os capítulos são parágrafos. E há um desejo que sejam um pensamento fluente, que não haja nenhuma interrupção. Uma coisa vai puxando a outra, como se fosse um desafogo daquele velho, falando, falando, até... até ele cansar [...] Aí retoma o segundo parágrafo e vai, vai, vai, mesmo que não tenha interlocutor, mesmo que os interlocutores sejam imaginários ou que estando ali não falem. Ele não quer saber ou pode ser surdo. Ou então fala sozinho (Holanda, 2009c).

É por meio do discurso da memória que o leitor tem acesso à personalidade e aos relacionamentos de Eulálio. Ao revolver o passado, em muitos momentos, Eulálio acentua em sua fala a aversão que tem aos povos do Norte brasileiro, como se estes fossem representantes de um "Brasil menor." As lembranças de Eulálio retomam, confusa e fragmentariamente, seus 100 anos de vida e as muitas vidas que circunscrevem os antepassados de um senhor, cuja família percorreu cenários políticos importantes da história do Brasil.

Em diversos momentos, o narrador relata os jogos políticos, as alianças feitas em nome do poder e alude, por meio do recorrente significante raiz, às raízes do Brasil, não por acaso, remetendo a Raízes do Brasil, título do livro de Sérgio Buarque de Holanda, como já mencionado anteriormente. $\mathrm{O}$ livro de Sérgio Buarque retrata exatamente o contexto político que acompanha o país desde o nascimento ficcional de Eulálio. Poder-se-ia dizer que, por essa estratégia romanesca, o narrador é transformado em leitor do livro de Sérgio Buarque, sem que isso explicitamente aconteça no romance.

Pela parte materna e paterna do narrador, as representações do poder de uma elite social brasileira se fazem presentes. O narrador relata que, "pelo [...] lado materno, o Rio de Janeiro parecia uma árvore genealógica" (Holanda, 2009a, p. 77-78) e que "os Montenegro possuíam metade do estado de Minas Gerais" (Buarque, 2009a, p. 59). O trisavô paterno de Eulálio teria chegado ao Brasil com a família real (1808) como "confidente de dona Maria Louca" (Holanda, 2009a, p. 50) e o bisavô, um traficante de escravos, que "foi feito barão [dos Arcos] por dom Pedro I. Esse traficante de escravos pagava altos tributos à coroa pelo comércio de mão de obra de Moçambique" (Holanda, 2009a, p. 79). O pai era senador e queria que o filho trilhasse os mesmos caminhos.

Imbricada à sua fala, a questão racial é aludida pela referência ao fato de o pai do tetravô ter comprado um chicote que passou de geração 
a geração e que, mesmo em contextos diferentes, pode ser considerado símbolo de autoridade e opressão. O pai do tetravô comprara o chicote com o intuito de fustigar os jesuítas. $\mathrm{O}$ trisavô o utilizava para dar lições "a marujo indolente", quando da vinda da corte portuguesa para o Brasil. O bisavô o utilizava quando "pegava negro fujão". O avô batia com ele em Balbino, escravo já alforriado e cujo sobrenome é também Assunção. Cabe ressaltar que o narrador afirma, com ironia, que o sobrenome, sem a distinção dada pela letra " $\mathrm{p}$ ", denota uma forma mais popular. O senador, pai de Eulálio, levava o chicote embaixo do paletó quando ia ao encontro de suas amantes. O chicote assume, portanto, vários significados que retratam papéis e comportamentos sociais. Por meio dele, a colonização portuguesa e a escravidão são trazidas à cena e mesmo que, posteriormente, ele passe a ser utilizado como objeto de perversão, ainda assim é um símbolo de poder.

Da mesma maneira que as referências ao chicote que, como vimos simboliza diferentes comportamentos da família de Eulálio, as cores preto e branco, recorrentes na obra, por vezes, são recurso para indicar atitudes preconceituosas da família. A alusão às cores é trazida, por exemplo, para, ironicamente, fazer menção ao tipo de sonho da personagem, como no caso do exemplo a seguir: "Até eu topar na porta de um pensamento oco, que me tragará para as profundezas, onde eu costumo sonhar em preto-e-branco" (Holanda, 2009a, p. 8).

Em outras cenas, a questão cromática aponta para a temática racial e para significados concretos alusivos à questão da cor da pele na sociedade brasileira, fisgados pelas lembranças de Eulálio. Nos exemplos a seguir, a cor da pele remete a outros preconceitos indicadores do comportamento da sociedade brasileira:

No entanto garanto que a convivência com Balbino fez de mim um adulto sem preconceitos de cor. Nisso não puxei ao meu pai, que só apreciava as loiras e as ruivas, de preferência sardentas. Nem minha mãe, que ao me ver arrastando a asa para Matilde, de saída me perguntou se por acaso a menina não tinha cheiro de corpo. Só porque Matilde era de pele quase castanha, era a mais moreninha das congregadas marianas que cantaram na missa do meu pai (Holanda, 2009a, p. 20).

Talvez até seja um avanço para os negros, que ainda ontem sacrificavam animais no candomblé, andarem agora arrumadinhos com a Bíblia debaixo do braço. Tampouco contra a 
raça negra nada tenho, saiba você que meu avô era um prócer abolicionista, não fosse ele e talvez todos aí estivessem até hoje tomando bordoada no quengo (Holanda, 2009a, p. 192).

Deve-se observar que a fala de Eulálio, nos excertos, traz muito do discurso da denegação, pois ao se ver como um adulto sem preconceitos de cor, que não saiu ao pai e nem à mãe, e que nada tem contra a raça negra, acentua, com as afirmações insistentes, seu preconceito.

É interessante perceber que o preto e o branco relacionam-se com o laranja, seja na forma cromática ou como significante e, para além disso, acompanha Balbino e Matilde, como evidenciado pelos excertos a seguir:

Chegado o dia, vestiu-se como achou que era de bom-tom, com um vestido de cetim cor de laranja e um turbante de feltro mais alaranjado ainda (Holanda, 2009a, p. 11).

Nem parei para pensar de onde vinha a minha raiva repentina, só senti que era alaranjada a raiva que tive da alegria dela (Holanda, 2009a, p. 12).

Dessa maneira, a cor laranja denota estar para além do seu significado cromático, sendo também o signo da referência a aspectos característicos de algumas personagens. Em Matilde, por exemplo, a cor laranja refere-se ao que a personagem tem para si como uma vestimenta de bom-tom e repercute sua personalidade alegre, sensual, e seu tom de pele. Talvez a "raiva alaranjada" que Eulálio sinta seja motivada pela alegria de Matilde, conotada na cor laranja. Por outro lado, com relação a Balbino, a cor/fruta acentua a maneira como Eulálio via os subalternos:

E o filho deste, Balbino Assunção Neto, um preto meio roliço, foi meu amigo de infância. Esse me ensinou a soltar pipa, a fazer arapucas de caçar passarinho, me fascinavam seus malabarismos com uma laranja nos pés, quando nem se falava em futebol [...] e então volta e meia lhe pedia um favor à-toa, mas para agradar a ele mesmo que era de índole prestativa (Holanda, 2009a, p. 18-19).

A visão do subalterno como portador de "índole prestativa" evidencia a maneira com a qual a elite de poder lidou com o corpo negro. Eulálio vale-se de categorias histórias para justificar seu desejo por Balbino, como se a história autorizasse as mais diversas formas de violência praticadas contra o negro. $\mathrm{O}$ desejo vem abarcado pela ideia de posse e do corpo negro enquanto objeto feito para servir ao branco: 
Durante um período, para você ter uma ideia, encasquetei que precisava enrabar o Balbino. Eu estava com dezessete anos, talvez dezoito, o certo é que já conhecia mulher, inclusive as francesas. Não tinha, portanto, a necessidade daquilo, mas do nada decidi que ia enrabar o Balbino. Então lhe pedi que fosse catar uma manga, mas tinha de ser aquela manga específica, lá no alto, que nem madura estava. Balbino pronto me obedecia, e suas passadas largas de galho em galho começaram a me atiçar [...] Só me faltava a ousadia para a abordagem decisiva, e cheguei a ensaiar conversas de tradição senhorial, direito de primícias, ponderações tão acima de seu entendimento, que ele já cederia, sem delongas (Holanda, 2009a, p. 19).

Pelo significante laranja, que aparece no romance sempre vinculado a Matilde e a Balbino, parece ressoar o desejo e repúdio que Eulálio nutre por essas duas personagens. Esse sentimento conflitante que acomete o narrador alude à maneira como a elite, metaforizada na figura de Eulálio, apropriou-se, ao longo de séculos, do corpo negro: ao mesmo tempo que era um corpo cuja cor despertava atração dos senhores brancos, era também o corpo a ser repudiado, explorado e menosprezado pelos cruéis trâmites do sistema escravagista brasileiro.

Em muitos momentos da narrativa, a mãe de Eulálio pergunta ao filho se ela, por ser "a mais moreninha das sete irmãs" não teria "cheiro de corpo", o que alude à maneira como o corpo negro era visto pela elite branca: o cheiro do corpo extenuado pelo trabalho era, simultaneamente, motivo de desejo e repúdio. Nesse sentido, o significante laranja está vinculado ao desejo, que é atravessado por questões raciais, e que remete também as nossas raízes brasileiras entrelaçadas ao nascimento de uma sociedade de formação escravagista. As memórias de Eulálio acionam, ainda, as memórias de um sistema escravocrata e do corpo negro escravizado e violentado pelos sistemas de poder vigentes ao longo de séculos.

Bhabha (1998) discorre acerca da violência instituinte na formação dos Estados coloniais e sublinha a questão da hierarquização dos corpos:

A construção do sujeito colonial do discurso, e o exercício do poder colonial através do discurso, exige uma articulação das formas da diferença - raciais e sexuais. Essa articulação torna-se crucial se considerarmos que o corpo está sempre simultaneamente (mesmo que de modo conflituoso) inscrito tanto 
na economia do prazer e do desejo como na economia do discurso, da dominação e do poder (Bhabha, 1998, p. 107).

Os corpos negros receberam marcas de posse e foram vítimas de violências que ultrapassam o corpo físico e se inscrevem na história truculenta das nações coloniais. Eulálio, ao relembrar o desejo pelo corpo negro de Matilde e também pelo corpo negro de Balbino, reativa as memórias relacionadas ao desejo e ao repúdio que o corpo não branco despertou no imaginário brasileiro ao longo de séculos.

Portanto, acentua-se, novamente, a ideia de que as memórias de Eulálio ativam não somente as reminiscências de um senhor no leito de um hospital. Por meio da estratégia narrativa de construção de uma personagem centenária cuja história familiar se imbrica à história do Brasil, fundem-se o público e o privado, o que permite perceber que as memórias particulares de Eulálio estão entrelaçadas às memórias do Brasil. O olhar de Eulálio para Matilde, reativado por meio de suas lembranças, possibilita entrever o olhar de todo um sistema colonial escravocrata para o negro. As exigências comportamentais que Eulálio fazia à Matilde retrazem as exigências que a elite branca sempre firmou diante dos negros que alcançavam alguma forma de poder ou status social. Eulálio deseja a Matilde do corpo negro hipersexualizado e erotizado pelo olhar do branco, desde a colonização. Mas, simultaneamente, quando esse passa a ser o corpo de sua esposa, ele exige sobriedade na maneira de se comportar, de se vestir. Dessa maneira, Eulálio busca que Matilde se aproxime da sobriedade dos tons cinzas, como anteriormente evidenciado, característicos de sua mãe, em detrimento dos tons alaranjados que a definem e ressaltam sua personalidade extravagante, aos olhos do narrador. Portanto, é pelo viés do embranquecimento que Eulálio "aceita" esse corpo negro ao seu lado. Ainda assim, Matilde não se submete a essa estratégia de apagamento de sua raça e, por isso, cada vez mais, desperta no narrador "raivas alaranjadas." Portanto, acentua-se novamente a ideia de que as memórias de Eulálio são atravessadas pelas memórias da colonização, do sistema escravagista, das memórias do corpo negro escravizado e da resistência do negro às exigências de submissão.

Amanda Braga (2015) através do livro História da beleza negra no Brasil: discursos, corpos e práticas, analisa o discurso que envolve a questão da beleza negra dos primórdios da formação do país até os dias atuais. Ela discorre acerca da truculência científica do colonialismo, dos 
zoológicos humanos e do uso da mulher coisificada, que remeteria a Saartije Baartman, símbolo do colonialismo científico. Na narrativa Leite derramado, o discurso de Eulálio acerca de Matilde, por vezes, encena a truculência herdada do período colonial: há momentos em que Matilde, sob o olhar de Eulálio e de sua mãe, parece exposta como objeto exótico, o que desperta curiosidade, desejo, mas também repulsa.

O racismo direcionado à Matilde é enfatizado nas atitudes de Eulálio e na fala de sua mãe. Pensando-se numa personagem cuja voz se funde às vozes da elite brasileira, o preconceito de Eulálio e sua mãe estão para além dos indivíduos e reverberam o racismo da elite brasileira desde a formação do Brasil. Nesse sentido, pode-se pensar no racismo e sua inscrição nos mecanismos do Estado e do poder. Sobre esse tema, Achile Mbembe (2014) acentua que, aperar de a raça não existir enquanto fato físico, antropológico ou genético, ela é uma ficção útil, um mito destinado a fundamentar e justificar o poder ocidental e suas práticas. Diante dessa perspectiva, o corpo negro é, historicamente, o "corpo de exploração":

O Negro não existe, no entanto enquanto tal. É constantemente produzido. Produzir Negro é produzir um vínculo social de submissão e um corpo de exploração, isto é, um corpo inteiramente exposto a vontade de um senhor, e do qual nos esforçamos para obter o máximo de rendimento (Mbembe, 2014, p. 40).

A relação de Eulálio e Matilde é, portanto, uma relação que aciona relações outras, que transcendem o âmbito individual. Reitera-se, pois, que as memórias de Eulálio, que reativam as falas de sua mãe acerca do corpo escuro de Matilde acionam as memórias de todo um sistema escravagista que perpassou e ainda perpassam o Brasil, através dos discursos e das práticas da elite brasileira, cujas bases são racistas.

O jogo cromático encenado pelas memórias do protagonista permeia a questão racial no Brasil e evidencia a situação privilegiada de uma classe social alta, cujos representantes são na maioria brancos, em detrimento de uma classe social mais baixa, representada, predominantemente, pelos negros, que, mesmo finda a escravidão, não deixou de ser explorada por uma elite branca. A união de Eulálio e Matilde demarca o ponto conflituoso que tange a sociedade brasileira: o branco e o preto, simbolizados pelo casamento de Matilde e Eulálio, denotam o lugar do conflito que acompanha a questão étnico-racial no Brasil. Portanto, a ideia de união abarcada pelo casamento das personagens é problematizada pelos conflitos e pela ideia de separação 
que o preto e o branco simbolizam no que concerne à questão relativa ao preconceito racial. Apesar de Matilde fazer parte de uma família com determinado "status" social, ela é filha de deputado, o fato de ser negra a coloca à margem do lugar ocupado pela elite brasileira. Essa separação denotada pela cor da pele é encenada repetidamente no romance pela fala preconceituosa de Eulálio, que relata que sua esposa, ao contrário de sua mãe, não domina os códigos da alta sociedade, pois não utiliza a língua portuguesa de maneira adequada, de acordo com os padrões da elite; não possui um comportamento marcado pela moderação; e não se veste de forma discreta, pois abusa de tons quentes e sensuais como o laranja, que destoa da sobriedade trazida pelos tons cinza e azul usados por sua mãe. É interessante relembrar que Matilde e Balbino, apesar de provocarem a repulsa de Eulálio, são também as personagens que aguçam seu desejo.

Para além da questão racial, muitas outras questões são trazidas por meio das memórias do narrador. A estrutura narrativa da obra acompanha a estrutura da memória: os capítulos são dispostos em uma ordem não cronológica, não linear, fragmentados e as repetições são recorrentes.

A questão da memória, na narrativa Leite derramado, faz-se presente tanto na forma quanto no conteúdo. A forma fragmentada com que a narrativa se delineia reitera, a todo o momento, partes da história cujas memórias de Eulálio tentam recuperar. Através da rememoração, o leitor é impelido a vasculhar o que nelas há de recalque, buscando desvendar os seus significados. É interessante observar, então, que, por trás dos significados que margeiam o narrador, desvelam-se outros que circunscrevem a sociedade brasileira desde o seu nascimento. Nas memórias da personagem Eulálio ressoam o Brasil pretérito, os preconceitos da elite, as relações de poder que se estabeleceram na nação brasileira. $\mathrm{O}$ movimento da narrativa procura imbricar as histórias familiares com a história social do Brasil, ressaltando as artimanhas da corrupção e dos jogos de poder. Portanto, as memórias de Eulálio são intencionalmente atravessadas pelas memórias do Brasil. É interessante observar o que a figura de Matilde metaforiza ao lado de Eulálio: ela em tudo difere da figura da mãe do narrador, parece ser o seu avesso, como anteriormente mencionado, mas, ao mesmo tempo, é sempre vista pelo narrador em comparação com a mãe, por vezes, confundindo-se com ela, como objeto de desejo. Mesmo ciente da aversão que Matilde despertava na mãe, Eulálio opta por se casar com ela. Inicialmente, pode-se pensar que, com essa atitude, o narrador 
escolhe trilhar seus próprios caminhos, mas, ao que parece, sua rebeldia não o afasta dos domínios que a figura materna exerce sobre ele, pois o que ele faz é sempre comparar Matilde com a mãe e perceber na esposa os mesmos deméritos sublinhados por sua progenitora. Acentua-se, pois, que a união de Matilde e Eulálio vale-se da perversidade e, dessa maneira, o narrador, em vez de caminhar com as próprias pernas, segue os passos de seu pai, cujas relações se pautaram, sobremaneira, na ideia de perversão.

Ainda defendendo-se a hipótese de que Eulálio é a metáfora da elite brasileira, pode-se dizer que as relações familiares do narrador, imersas na perversão, principalmente, no que se refere à Matilde e a Balbino, metaforizam as relações também perversas de uma estrutura de poder com relação à raça negra. Pode-se dizer, portanto, que romance familiar de Eulálio toca em questões outras como a do próprio nascimento da nação brasileira, imbricado em relações conflituosas. Ao longo da história do Brasil, tentou-se sacralizar a ideia de uma "origem pura", que sempre remetia à Europa, e negar as misturas advindas das heranças culturais africanas e indígenas em nosso país. Essa questão se encena no romance de Chico Buarque e pode ser percebida através do próprio costume de Eulálio em privilegiar a norma padrão e os padrões linguísticos portugueses assumidos pela elite, fechando-se aos hibridismos e atualizações e apropriações às quais a língua sempre esteve sujeita. A narrativa também encena a questão da ilegitimidade da origem da nação quando o autor, estrategicamente, constrói um narrador, cuja imagem transcende o indivíduo e metaforiza a história do Brasil, que, apesar de contada do ponto de vista da elite, é desconstruída por meio do discurso irônico do narrador. Eulálio, ao debochar do contexto em que vive no século XXI, desprovido dos privilégios da elite da qual fez parte, permite que o leitor vislumbre os preconceitos que perpassam a origem da nação brasileira: uma elite de poder que sempre se mirou no legado europeu, escolhendo, assim, fechar os olhos para culturas que não espelhassem a europeia. As misturas raciais e sociais encenadas na narrativa possibilitam, pois, desconstruir a ideia de família legítima, pautada no ideal de pureza, neuroticamente construído pela ideologia colonialista. Ao expor, ironicamente, o discurso da elite, o narrador expõe também os pilares sobre os quais a nação brasileira se ancorou: estruturas de poder sempre espelhando sua fala no modelo europeu e negando, assim, as heranças culturais indígenas e africanas. 


\section{Considerações finais}

No romance Leite derramado a identidade de Eulálio foi, estrategicamente, construída a partir de memórias comprometidas pela senilidade. Os esquecimentos de Eulálio, enquanto estratégia textual, marcam o jogo entre o lembrar e o esquecer no qual a narrativa se ancora. Esse fato provoca no leitor a desconfiança com relação ao discurso memorialístico desenvolvido por esse senhor. Ao colocar em suspeita a fala de Eulálio, pôde-se perceber que a mesma suspeita recaiu sobre a fala da elite brasileira, que desde o seu nascimento, de maneira equivocada, alicerçou-se na fusão entre o público e o privado, fazendo com que as instituições públicas se constituíssem como uma espécie de extensão do domínio privado e da família. Dessa maneira, a elite brasileira se ancorou na imagem do patriarca e ampliou seus domínios, trazendo para o espaço público o legado patriarcal que sempre a sustentou no âmbito particular. A imbricação entre público e privado permitiu perceber que, em Leite derramado, as questões relativas à memória são atravessadas pela história do Brasil: a família e a rede de relações particulares do indivíduo se entremeiam ao poder público e configuram o cenário político do país. Dessa forma, a história da família de Eulálio se entretece à história do Brasil, desde os tempos do Império até o século XXI.

O discurso de Eulálio, ao abarcar os preconceitos da elite, que não aceita as misturas étnicas, linguísticas e raciais, exibe os preconceitos naturalizados no país. A ironia presente na narrativa buarquiana estabelece uma espécie de confronte entre o indivíduo liberto das censuras que acometem o sujeito e as máscaras sociais, que não permitem efetivamente que a personagem, envolta no preconceito, deixe absolutamente expostas. O recurso da ironia, presente ao longo de todo o romance, destaca o fato de Eulálio, representante de uma elite de poder, ver-se, no presente, no fim da vida, exibindo um corpo adoecido que remete, metaforicamente, ao do próprio Estado brasileiro.

\section{Referências}

BHABHA, Homi K. (1998) Locais da cultura. In: BHABHA, Homi K. O local da cultura. Belo Horizonte: Editora da UFMG. 
BRAGA, Amanda (2015). A história da beleza negra no Brasil: discursos, corpos e práticas. São Paulo: Editora da UFScar.

HOLANDA, Chico Buarque de (2009a). Leite derramado. São Paulo: Companhia das Letras.

HOLANDA, Chico Buarque de (2009b). "Mas Chico é nome de escritor ruim". Público, Lisboa, Suplemento Ípsilon, 17 jul. On-line. Disponível em: <https://goo.gl/PuipCy>. Acesso em: 8 nov. 2017.

HOLANDA, Chico Buarque de (2009c). Chico Buarque: "O meu mundo é o dos músicos". Entrevista a Ana Cristinma Leonardo. Expresso, Paço de Arcos, 11 ago. On-line. Disponível em: <https://goo.gl/ZTovM9>. Acesso em: 8 nov. 2017.

HOLANDA, Chico Buarque de (2009d). Fortuna crítica de Leite Derramado. Chico Buarque. Site pessoal. On.-line. Disponível em: <https://goo.gl/stXCkJ>. Acesso em: 8 nov. 2017.

HOLANDA, Sérgio Buarque de (2014). Raízes do Brasil. São Paulo: Companhia das Letras.

MBEMBE, Achille (2014). Crítica da razão negra. Tradução de Marta Lança. Lisboa: Antígona.

MENESES, Adélia Bezerra de (2002). Desenho mágico: poesia e política em Chico Buarque. São Paulo: Ateliê.

SARMENTO, Alexsandra Loiola (2015). "O Purgatório" d'A Divina Comédia vertido em Leite Derramado: tradição, mito e ironia no romance de Chico Buarque. 2015. Tese (Doutorado em Letras) - Pontifícia Universidade Católica de Minas Gerais, Belo Horizonte.

Recebido em 2 de março de 2017.

Aprovado em 28 de maio de 2017.

\section{resumo/abstract/resumen}

\section{As raízes do Brasil em Leite derramado, de Chico Buarque}

Lílian Paula Serra e Deus

O presente artigo tem como objetivo investigar as estratégias textuais das quais a literatura se vale, mais especificamente, a narrativa buarquiana Leite derramadopara encenar, pelos caminhos da ficção, a fusão entre o público e o 
privado que acompanha o contexto histórico-político brasileiro há séculos. Nesse sentido, busca-se demonstrar como as raízes de Eulálio, explicitadas em seu discurso memorialístico, são atravessadas pelo que o historiador Sérgio Buarque de Holanda denominou de raízes do Brasil.

Palavras-chave: Chico Buarque, Leite derramado, memórias, história.

\section{The roots of Brazil in Leite derramado, by Chico Buarque}

\section{Lílian Paula Serra e Deus}

This article investigates the textual strategies that literature employs. More specifically, the essay looks into Chico Buarque's use of these strategies in his novel Leite derramado to stage, through the paths of fiction, the fusion between public and private that has characterized the Brazilian historical and political contexts. In this context, the essay demonstrates how Eulálio's orgins, articulated in his memorialistic discourse, are infused by what the historian Sérgio Buarque de Holanda has called the roots of Brazil.

Keywords: Chico Buarque, Leite derramado, memories, literature, history.

\section{Las raíces de Brasil em Leite derramado, de Chico Buarque}

\section{Lílian Paula Serra e Deus}

El presente artículo tiene como objetivo investigar las estrategias textuales de las cuales la literatura se vale, más específicamente, la narrativa buarquiana Leite derramado, para escenificar, por los caminos de la ficción, la fusión entre lo público y lo privado que acompaña el contexto histórico-político brasileño hace siglos. En ese sentido, se busca demostrar cómo las raíces de Eulálio, explicitadas en su discurso memorialístico, son atravesadas por lo que el historiador Sérgio Buarque de Holanda denominó raíces del Brasil.

Palabras clave: Chico Buarque, Leite derramado, memorias, raíces del Brasil, literatura, historia. 